\title{
Intracranial nerve repair: a review of experimental and clinical studies
}

\section{Tomas Menovsky, M.D., and Jacobus J. van Overbeeke, M.D., Ph.D.}

Department of Neurosurgery, Academic Hospital Nijmegen St. Radboud, Nijmegen, The Netherlands

With recent developments in neurosurgery and related disciplines, more aggressive approaches are being made for various lesions of the skull base, and, as a consequence, cranial nerves are more frequently damaged, which causes significant morbidity. The authors review experimental and clinical studies involving surgical repair of severed cranial nerves and provide evidence that some degree of functional regeneration occurs. Functional recovery after repair is mainly dependent on the preoperative function of the muscle-nerve unit and the morphological organization of the nerve; the more complex the organization, the lesser the degree of functional recovery. The beneficial effect of surgical repair on postoperative morbidity is outlined together with suggestions for future research.

Key Words * cranial nerve * nerve regeneration * skull base surgery * suture

Developments in neuroanesthesiology, neuroradiology, computer-assisted planning of operations, and microneurosurgery together with a better understanding of microanatomy have resulted in a more frequent and more aggressive surgical approach for complex neoplastic and vascular lesions of the skull base. $[2,13,31,65,78,81,82]$ As a consequence, cranial nerves three to six are more frequently at risk during surgery in the cavernous sinus region, whereas cranial nerves seven to 12 can be injured during surgery in the posterior fossa region. In these surgical procedures, cranial nerves may be sacrificed for the sake of complete tumor removal or to achieve a satisfactory operative approach; nerve injuries can also occur during surgical manipulations.

For many years, the intracranial parts of the cranial nerves were thought to be unreparable. This was partly due to the technical difficulties in repairing these delicate structures as well as the belief that the cranial nerves did not regenerate. In the last decennium, several experimental and clinical studies proved the opposite. In this review, studies on intracranial nerve repair are analyzed and future developments are outlined.

\section{ANATOMICAL AND HISTOLOGICAL CONSIDERATIONS}

Although some surgical principles of peripheral nerve surgery also apply to cranial nerves, there are distinct anatomical and histological differences between the cranial and peripheral nerves.[63,84,87] Therefore, cranial nerve repair should have its own surgical concept adapted to the specific structure of the nerves and its regenerative potential. For convenience, cranial nerves will be taken to consist of those 
parts of cranial nerves that are located intracranially. No results will be reported on repair of extracranial portions of the nerves. We will avoid the use of the word "anastomosis" as a term for nerve repair in this paper. Although anastomosis is frequently (but incorrectly) used in many papers on nerve repair, fundamentally, it means coaptation of a hollow structure.

\section{Anatomical Considerations}

From an anatomical point of view, the cranial nerves lie freely in the cerebrospinal fluid (CSF) throughout their length. $[47,48,63,84,87]$ They are only fixed at the exit point from the brainstem and at the exit point of the skull. Because the cranial nerves are not subjected to movements or directly embedded in tissue, they are not adapted to stretching or any mechanical forces from outside. There is almost no surrounding tissue in close contact with the cranial nerves, implying that cranial nerves rely on direct vascularization of the supplying vessels and vessels in pia mater.[46-48]

Compared to peripheral nerves, the cell bodies of the axons of the cranial nerves are very close to the possible site of injury. Whereas in peripheral nerves the distance between injury and the cell body can be longer than $100 \mathrm{~cm}$, in cranial nerves this distance is at most a few centimeters. This has serious consequences for the regenerative potential. It is known that lesions close to the cell body are accompanied by impaired regeneration. $[23,37,43,58,64]$ The interruption of the continuity of an axon leads to characteristic changes in the various parts of the neuronal unit preparing the cell for regeneration of the cell and its distal segment.[33,73] After transection, the cell body looses its connection with a substantial part of its plasma. In the cell bodies the proteosynthesis is clearly increased. The axons by themselves possess almost no capacity to synthesize macromolecules, and thus they depend completely on the perikarya to supply these substances during the process of regeneration. The chromatolytic hypertrophic changes occurring in the cell body are more pronounced the closer the transection is made to the nerve cell.[88] The regeneration of axons in these lesions is consequently impaired because the amount of distal axon to be replaced may exceed the metabolic activity of the cell. Also, the amount of total neuron cut away and separated is larger, and thus the amount of cellular disruption is greater. Sometimes, this loss will exceed the tolerance of the neuron. The increased metabolism will be selectively used for survival of the cell body without regeneration of the distal segment.

Little is known about the effect of CSF on cranial nerve regeneration. It is likely that the CSF has a metabolic relationship with the endoneurial compartment of the nerves. Circulating hormones and other substances in the CSF could influence the nerve regeneration. Adverse effects can also be expected, such as from circulating blood products and various inflammatory cells after infection in the CSF. The local neurotrophic factors produced by the distal stump of the transected nerve may be diffused by the CSF, thus diminishing axonal outgrowth.

\section{Histological Considerations}

From a histological point of view, the cranial nerves lack an epineurial layer. They also lack a firm perineurium, and they are enveloped by only a single or double layer of flattened sheath cells without a continuous basal lamina. $[48,61,62]$ The collagen content of cranial nerves is much less than that of peripheral nerves, and there is no interfascicular connective tissue that separates fibers into branches. Although it is believed that there is a certain degree of somatotopy in cranial nerves, there is no macroscopical fascicular organization. Also, the intracranial segments of the cranial nerves undergo a transformation in their structure at some point along their length. This transition zone, which is a wedge-shaped area extruding from the brainstem into the nerve, differentiates between central 
myelination (by oligodendrocytes) and peripheral myelination (by Schwann cells).[63,84] As a consequence of these structural properties, cranial nerves are mechanically much less stable and more vulnerable to any type of surgical manipulation than peripheral nerves.

\section{ANIMAL STUDIES}

Saitoh[68] was the first to report on oculomotor nerve regeneration after surgical repair in dogs. Almost complete transection of the nerve was followed by suture repair. Eight of the 11 dogs regained nearly normal eye movement 9 months after repair. Moderate pupil constriction was noted in nine dogs and normal constriction in two. Subsequently, Sandvoss, et al.,[71] performed a series of experimental repairs of the oculomotor nerve in cats. The nerves were glued either with Aron Alpha (Japanese fibrin glue), with heterogeneous fibrin glue, or coapted with lateral slit silicone cuffs. Three months after surgery, clinical investigation, electromyography, and histological studies showed optimal regeneration in fibrin glue repairs. Aron Alpha repairs were unfavorable because of atrophy and scar adhesions. Control cats that had not undergone repair showed no signs of regeneration. This study was followed by investigations of abducens nerve repair in cats.[72] Nerves glued together with fibrin glue revealed good reinnervation within 3 months, with ideal parallel alignment of the nerve fibers at the repair site. Nerve repair using Tabotamp or Aron Alpha resulted in neuroma formation, adhesions, and atrophy of the nerve with impaired recovery. Fisch, et al.,[29] showed that facial nerve repair performed with a collagen splint avoids fibrosis and leads to minimal ingrowth of connective tissue in cats.

Groups led by Fernandez and Pallini[25-27,64] investigated nerve morphometry and functional regeneration after oculomotor nerve repair. In rats, the oculomotor nerve was sectioned and the nerve stumps were coapted with plasma clot.[26] Functional recovery of the nerve was assessed by measurements of the pupillary diameter and the ocular displacement evoked by vestibular stimulation. In the postoperative period, pupil diameter showed a progressive reduction, whereas the horizontal and vertical ocular displacements were decreased. The vestibular stimulation in the horizontal plane evoked anomalous eye movements with vertical components. The regenerated nerves showed a progressive increase of axonal diameter and myelin sheath thickness. Somatotopic organization of the motorneurons of the reinnervated muscles showed less specific, bilateral representation in the midbrain compared with normal muscles having unilateral representation. This was ascribed to a plastic response of the brainstem neurons to misdirected regrowth of axons in the distal nerve. In a study of the repair of cranial nerves three and six in rats, functional recovery of the abducens nerve was much better than that of the oculomotor nerve, suggesting that complexity of the nerve motor system organization is a major factor influencing the functional outcome.[25] In a study in guinea pigs, the effect of proximal and distal transection on oculomotor nerve regeneration was investigated.[64] The nerve was sectioned at the edge of the tentorium or at the orbital fissure and then coapted by plasma clot. After proximal repair, functional recovery varied among different animals and remained stable. In poorly regenerated nerves, aberrant eye movements were found, and the somatotopy of the neurons was greatly altered. After distal repair, extraocular motility had recovered and no aberrant eye movement was observed.

A comparative study of laser-assisted nerve repair versus fibrin glue was performed by Seifert and Stolke[75,76] in cats. The cut oculomotor nerve was either fused together with a CO2 $\mathrm{mW}$ laser or coapted with fibrin glue. Regeneration (evaluated by pupil diameter measurements) was "almost complete" in four nerves and "partial" in two cats that underwent laser-assisted repair.

Histomorphological examination revealed good regeneration across the laser repair without significant scarring effect or constriction at the repair site. One partial recovery and separation of two nerves was 
found in fibrin glue repair.

Recently, Glasby, et al.,[32] repaired the facial nerve in the cerebellopontine angle of sheep. The transected facial nerve was repaired with freeze-thawed muscle autografts that were $5 \mathrm{~mm}$ in length and then coapted with fibrin glue. One year after surgery, clinical improvement of facial paralysis and a return of the corneal blink reflex were noted in five of six sheep. In one case the nerve was separated. Neurophysiological examination confirmed the return of function with nearly similar motor latencies and conduction velocity between the normal and repaired nerves. Morphological examination showed small but normally myelinated nerve fibers in the distal nerve segment.

\section{CLINICAL STUDIES}

\begin{tabular}{|c|c|c|c|c|c|c|c|c|c|}
\hline \multicolumn{10}{|c|}{$\begin{array}{c}\text { TABLE } 1 \\
\text { SUMMARY OF DATA ON INTRACRANIAL THRD AN }\end{array}$} \\
\hline \multirow[b]{2}{*}{ Authors \& Year } & \multirow[b]{2}{*}{$\begin{array}{l}\text { Cranial } \\
\text { Nerve }\end{array}$} & \multirow[b]{2}{*}{$\begin{array}{l}\text { Type of } \\
\text { Repair }\end{array}$} & \multirow[b]{2}{*}{$\begin{array}{l}\text { No. of } \\
\text { Cases }\end{array}$} & \multirow[b]{2}{*}{$\begin{array}{l}\text { Coaptation } \\
\text { Tectnique }\end{array}$} & \multirow[b]{2}{*}{$\begin{array}{c}\text { Follow-Jp } \\
\text { Review (mos) }\end{array}$} & \multicolumn{4}{|c|}{ Ocud onotor Function* } \\
\hline & & & & & & Exced- & Good & Fair & Poor \\
\hline Imabuchi, et al., 1982 & III & end-to-end & 1 & sutures & 18 & & 1 & & \\
\hline Grimson, et al. 1984 & IV & end-to-end & 1 & sutures & 5 & 1 & & & \\
\hline Deruty, et al., 1988 & III & end-to-end & 1 & suture s† & 18 & & 1 & & \\
\hline Ferrier, et al., 1992 & IV & end-to-end & 1 & sutures & 6 & 1 & & & \\
\hline Krajemski, 1992 & III & graft (1 cm) & 1 & sutures & 24 & & 1 & & \\
\hline \multirow[t]{6}{*}{ Sekhar, et al., 1992} & III & $\begin{array}{l}\text { end-to-end } \\
\text { graft }\end{array}$ & $\begin{array}{l}1 \\
1\end{array}$ & $\begin{array}{l}\text { suture sfibrin glue } \\
\text { fitrin glue }\end{array}$ & $\begin{array}{l}36 \\
14\end{array}$ & & & 1 & 1 \\
\hline & IV & end-to-end & 1 & suture sifitrin glue & 12 & & & 1 & \\
\hline & $\mathrm{v}^{1}$ & graft & 3 & suture sil trin glue & $18-52$ & & & 1 & 2 \\
\hline & artial) & graft & 1 & & 24 & & & 1 & \\
\hline & VI & end-to-end & 3 & suture sifitrin glue & $25-60$ & & & 1 & 2 \\
\hline & & graft & 6 & fitrin glue & $21-35$ & 1 & 1 & 3 & 1 \\
\hline Sindou, et al., 1992 & IV & graft (1 cm) & ) 1 & fitrin glue & 7 & 1 & & & \\
\hline \multirow[t]{2}{*}{ Present study } & IV & graft $(0.5$ on & m) 1 & suture sit brin glue & 5 & 1 & & & \\
\hline & $\mathrm{vI}$ & graft (1.5 or & & suture sif brin glue & 6 & & 1 & & \\
\hline
\end{tabular}

Most articles on the repair of cranial nerves three to six consist of case reports.[15,28,34,38,44,80,83] Only Sekhar, et al., [79] published a relatively large series on cranial nerve repairs during operations for tumors in the cavernous sinus region. The data from these case reports are summarized in Table 1 . The ocular motility grading system[79] for evaluation of cranial nerves three to six is given in Table 2. For the facial nerve, the published series are obviously much larger.[1,3,8,9,19-22,24,29,39-42,49,52,66,69,86,90] In some cases of cranial nerve repair, the follow-up period was relatively short. It must be stated that the continued recovery after nerve repair can proceed for 5 to 10 years after surgery, although the most significant improvement is observed within the first 2 years after surgery. 


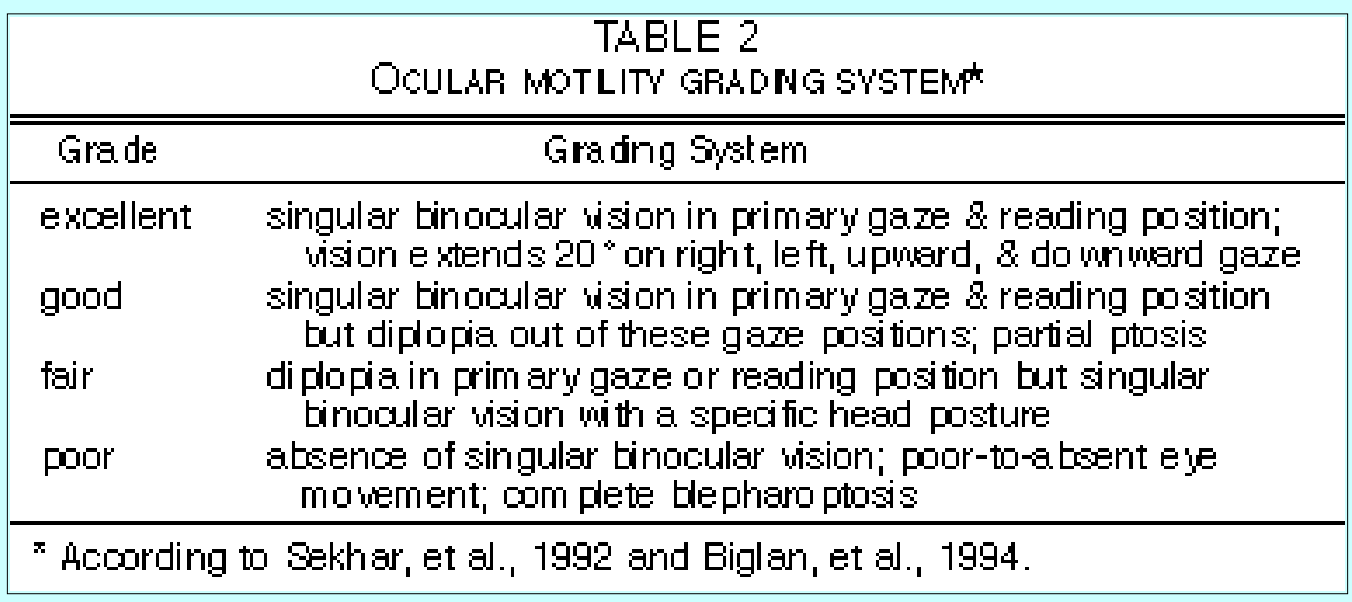

\section{Oculomotor Nerve}

Iwabuchi, et al.,[38] were the first to perform an end-to-end suture repair of the oculomotor nerve after accidental transection during surgery of a parasellar adenoma. One and one-half years after repair, adduction of the left eyeball was almost normal and the patient did not suffer from diplopia. Deruty, et al.,[15] describe repair of the oculomotor nerve after transection (several millimeters from its entry into the brainstem) during excision of a schwannoma. After 18 months, ptosis had disappeared and adduction of the eye reappeared. The patient continued to have an absent pupil reflex to light and vertical movements of the eye were restricted. Krajewski[44] repaired an oculomotor nerve that was damaged during surgery for a lateral retrosellar adenoma. The patient showed partial recovery of nerve function 2 years after surgery. Normal horizontal gaze was restored, ptosis was absent, and the pupil reacted slowly to light.

Two cases of oculomotor nerve repairs were reported in the series by Sekhar, et al.[79] In the first case, an end-to-end nerve repair was performed with sutures and fibrin glue. The functional recovery of the nerve after 36 months was partial but similar to the preoperative state. The second case was a graft repair over a distance of $3 \mathrm{~cm}$ using sutures and fibrin glue. After 14 months, the functional return consisted of slight pupil reaction to light, partial ptosis, and movements of the eye in all directions.

\section{Trochlear Nerve}

Grimson, et al.,[34] repaired a trochlear cranial nerve that was transected during aneurysm surgery. Within 5 months after surgery, the superior oblique palsy had resolved with full recovery of the vertical gaze of the eyes and a return of the right optic disc to its normal anatomical relationship with the fovea. Also Ferrier, et al.,[28] Sindou, et al.,[83] and van Overbeeke (unpublished results) describe complete return of trochlear nerve function after end-to-end nerve repair.

\section{Trigeminal Nerve}

Sekhar, et al.,[79] reported on four cases of trigeminal nerve repair. In three patients, the ophthalmic root was repaired with nerve grafts. The corneal reflex was complete in one patient and incomplete in another patient. The complete trigeminal nerve was partially injured in one case and consequently repaired with a nerve graft using sutures. In this patient, recovery was also partial.

\section{Abducens Nerve}

Nine cases of abducens nerve repair were described by Sekhar, et al.[79] End-to-end repair was 
performed in three nerves; functional recovery was complete in one case, good in the second, and poor but similar to the preoperative state in the third case. Six nerves were reconstructed with nerve grafts. In one case with a partially injured nerve, complete recovery was attained. In three patients the recovery was partial. In two patients who underwent direct neurotization of the nerve graft (insertion of the nerve graft into the lateral rectus muscle) recovery was excellent and poor, respectively.

\section{Facial Nerve}

Because the facial nerve is quite frequently damaged during surgery for cerebellopontine angle tumors or vascular lesions such as aneurysms, vast experience in the repair of this nerve has been accumulated. Until the mid 1970s, facial paralysis that occurred in association with performing intracranial procedures was managed by nerve substitution techniques such as hypoglossal-facial coaptation or facial-spinal coaptation. Pioneered by the work of Dott[16,17] and Drake,[19-22] microsurgical techniques have permitted restoration of the facial nerve by end-to-end repair or grafting techniques. In 1936, Dott was the first to perform an intracranial-extratemporal bypass of the facial nerve with a sural graft after total removal of a large acoustic neuroma.[17] In 1960 Drake was the first to perform secondary grafting[19] and later end-to-end repair[20-22] after removal of acoustic tumors in four patients. These patients showed "gratifying recovery of facial function and especially a useful degree of emotional movement." Soon it was shown that the results of primary repair were superior to those obtained by the nerve substitution techniques.[9] 


\begin{tabular}{|c|c|c|c|c|c|c|c|}
\hline \multirow[b]{2}{*}{ Authors \& Year } & \multirow{2}{*}{$\begin{array}{l}\text { Type of } \\
\text { Repair }\end{array}$} & \multirow{2}{*}{$\begin{array}{l}\text { No. of } \\
\text { Cases }\end{array}$} & \multirow{2}{*}{$\begin{array}{l}\text { Coaptation } \\
\text { Tectmique }\end{array}$} & \multirow{2}{*}{$\begin{array}{c}\text { Follow-dp } \\
\text { Review (mos) }\end{array}$} & \multicolumn{3}{|c|}{ Facial Neve Function ${ }^{*}$} \\
\hline & & & & & Good & Fair & Poor \\
\hline Drake, 1972 & end-to-end & 7 & sutures & & 4 & - & 3 \\
\hline & graft & 4 & & & 3 & - & 1 \\
\hline Yasargil, et al., 1977 & end-to-end & 11 & sutures & & 4 & 5 & 2 \\
\hline Erackmann, et al., 1978 & $\begin{array}{l}\text { end-to-end } \\
\text { graft }\end{array}$ & $\begin{array}{l}7 \\
2\end{array}$ & sutures & $24-84$ & $\begin{array}{l}6 \\
2\end{array}$ & $\begin{array}{l}- \\
-\end{array}$ & $\frac{1}{-}$ \\
\hline Barrs, et al., 1984 & $\begin{array}{l}\text { end-to-end } \\
\text { graft }\end{array}$ & $\begin{array}{r}18 \\
6\end{array}$ & suture s/A vitene & $24-72$ & $\begin{array}{l}15 \\
4\end{array}$ & $\begin{array}{l}- \\
-\end{array}$ & $\begin{array}{l}3 \\
2\end{array}$ \\
\hline May, 1986 & $\begin{array}{l}\text { end-to-end } \\
\text { graft }\end{array}$ & $\begin{array}{r}8 \\
27\end{array}$ & sutures & $>24$ & $\frac{7}{14}$ & $\overline{4}$ & $\begin{array}{l}1 \\
9\end{array}$ \\
\hline Pluchino, et al., 1986 & $\begin{array}{l}\text { end-to-end } \\
\text { graft }\end{array}$ & $\frac{23}{3}$ & sutures & $2-108$ & $\frac{6}{-}$ & $\frac{9}{-}$ & $\frac{5}{3}$ \\
\hline Fisch, et al., 1987 & graft & 8 & $\begin{array}{l}\text { collagen splint } \\
\& \text { fitrin glue }\end{array}$ & $36-120$ & 8 & - & - \\
\hline $\begin{array}{l}\text { Jääskeläjnen, et al., } \\
1990\end{array}$ & $\begin{array}{l}\text { end-to-end } \\
\text { graft }\end{array}$ & 20 & sutures & $36-117$ & $\begin{array}{l}9 \\
2\end{array}$ & $\overline{-}$ & $\begin{array}{l}11 \ddagger \\
3 \ddagger\end{array}$ \\
\hline King, et al., 1990 & graft & 8 & $\begin{array}{l}\text { sutures' } \\
\text { fitrin glue }\end{array}$ & - & 1 & 5 & 2 \\
\hline Kanzaki, et al., 1991 & end-to-end & 6 & $\begin{array}{l}\text { suture or } \\
\text { fitrin glue }\end{array}$ & $12-144$ & 3 & - & 3 \\
\hline Leutje, et al., 1991 & $\begin{array}{l}\text { graft } \\
\text { end-to-end } \\
\text { graft }\end{array}$ & $\begin{array}{r}3 \\
18 \\
1\end{array}$ & suture s/a vitene & $\begin{array}{l}6-46 \\
>18 \\
>18\end{array}$ & $\begin{array}{l}1 \\
7 \\
-\end{array}$ & $\begin{array}{l}-\overline{8} \\
1\end{array}$ & $\begin{array}{l}2 \\
3 \\
-\end{array}$ \\
\hline Arriaga, et al., 1992 & $\begin{array}{l}\text { end-to-end } \\
\text { graft }\end{array}$ & $\begin{array}{r}14 \\
9\end{array}$ & suture s/A vitene & $8-96$ & $\begin{array}{l}5 \\
1\end{array}$ & $\begin{array}{l}2 \\
3\end{array}$ & $\begin{array}{l}6 \\
4\end{array}$ \\
\hline Ebersold, et al., 1992 & $\begin{array}{l}\text { end-to-end } \\
\text { graft }\end{array}$ & $\begin{array}{l}7 \\
1\end{array}$ & sutures & 12 & $\|$ & $\|$ & $\|$ \\
\hline Ste phanian, et al., 1992 & graft & 22 & suturess & $6-65$ & 10 & 8 & 4 \\
\hline King, et al., 1993 & end-to-end & 6 & $\begin{array}{l}\text { suturesi } \\
\text { fitrin glue }\end{array}$ & $24-108$ & 4 & - & 2 \\
\hline Elomstedt, et al., 1994 & graft & 12 & & & 5 & 2 & 5 \\
\hline NF2† & $\begin{array}{l}\text { end-to-end } \\
\text { graft }\end{array}$ & $\begin{array}{l}6 \\
2\end{array}$ & sutures & $\begin{array}{r}20-118 \\
66-68\end{array}$ & $\frac{2}{-}$ & $\begin{array}{l}1 \\
1\end{array}$ & $\begin{array}{l}3 \\
1\end{array}$ \\
\hline non-NF2† & end-to-end & 17 & $\begin{array}{l}\text { suture s' } \\
\text { fitrin glue }\end{array}$ & $21-114$ & 7 & 7 & 3 \\
\hline Samii \& Matthies, 1994 & $\begin{array}{l}\text { graft } \\
\text { end-to-end }\end{array}$ & 17 & $\begin{array}{l}\text { suturesi } \\
\text { fitrin glue }\end{array}$ & $\begin{array}{r}47-104 \\
6-94\end{array}$ & $\begin{array}{c}3 \\
12\end{array}$ & $\begin{array}{l}1 \\
5\end{array}$ & $\frac{1}{-}$ \\
\hline total & $\begin{array}{l}\text { graft } \\
\text { end-to-end } \\
\text { graft }\end{array}$ & $\begin{array}{r}27 \\
185 \\
145 \\
\end{array}$ & & $\begin{array}{r}14-126 \\
9 \\
7\end{array}$ & $\begin{array}{c}20 \\
91(49 \%) \\
74(51 \%)\end{array}$ & $\begin{array}{c}5 \\
37(20 \%) \\
30(21 \%)\end{array}$ & $\begin{array}{c}2 \\
46(25 \%) \\
39(27 \%)\end{array}$ \\
\hline $\begin{array}{l}\text { "Three categories are } \\
\text { and Ill of the House-Bra } \\
\dagger \text { A fter removal of Neu } \\
\text { after secondary reanim } \\
\text { Jä̈skeläjnen, et al., } 199 \\
\text { † House-Brackmann G } \\
\text { II The results were pres } \\
\text { \& In some cases fitrin }\end{array}$ & $\begin{array}{l}\text { Used: good, } \\
\text { ckm ann scale } \\
\text { rofitromatosi } \\
\text { ation prooed } \\
0 . \\
\text { rade IV to VI } \\
\text { ented with th } \\
\text { glue was also }\end{array}$ & $\begin{array}{l}\text { modera } \\
\text { e, fair to } \\
\text { s-2 aco } \\
\text { dures. } \\
\text { ose act } \\
\text { os used. }\end{array}$ & $\begin{array}{l}\text { te, and poor. The } \\
\text { Gade IV, and } P \\
\text { ustic neuromas; } \\
\text { Bome of these } \\
\text { hieved after prese }\end{array}$ & $\begin{array}{l}\text { good grade } \\
\text { poor to Grade } \\
\text { the results ar } \\
\text { patients ha ie } \\
\text { er vation of the }\end{array}$ & $\begin{array}{l}\text { is equi we } \\
\text { s } v \text { and } \\
\text { ve preser } \\
\text { e been } \\
\text { e facial } n\end{array}$ & $\begin{array}{l}\text { alent to Gr } \\
\text { Wl. } \\
\text { nted in sol } \\
\text { reported } 6 \\
\text { ier'e. }\end{array}$ & $\begin{array}{l}\text { ades I, II, } \\
\text { me cases } \\
\text { earlier by }\end{array}$ \\
\hline
\end{tabular}

The data from large series of intracranial facial nerve repair are summarized in Table 3; most of the articles deal with acoustic neuroma surgery. Besides these series there are several single case reports on intracranial facial nerve repair after both trauma[67] and tumor removal;[18,59] all of them show that facial nerve function recovers to some degree. For interpretation of the results after facial nerve repair, a 
simplified House-Brackmann[36] grading system was used as proposed by King, et al.,[42] (Table 4). Good results are obtained in approximately $50 \%$ of the patients.

\begin{tabular}{|c|c|}
\hline \multicolumn{2}{|c|}{$\begin{array}{c}\text { TABLE } 4 \\
\text { SIMPLIFIED HOUSE-BRACKMANN GRADNG SVSTEMt }\end{array}$} \\
\hline Grade & Outcome \\
\hline I: norm al & normal facial function \\
\hline II: mild dystunction & $\begin{array}{l}\text { minimal facial weakness or other defect suf- } \\
\text { ficient to pre vent dassification as Grade I }\end{array}$ \\
\hline III: moderate dysfunction & $\begin{array}{l}\text { pronounced facial we akness irrespective of } \\
\text { synkinesis but with complete eye dosure }\end{array}$ \\
\hline $\begin{array}{l}\text { IV: moderately se vere } \\
\text { dystunction }\end{array}$ & $\begin{array}{l}\text { same as Grade III but without } \\
\text { complete eve closure }\end{array}$ \\
\hline V: severe dysfunction & $\begin{array}{l}\text { return of tone with or without minimal muscular } \\
\text { contraction }\end{array}$ \\
\hline VI: total paralysis & $\begin{array}{l}\text { complete facial paralysis: no tone or } \\
\text { muscular contraction }\end{array}$ \\
\hline
\end{tabular}

\section{Cranial Nerves Eight, Nine, 10, 11, and 12}

There are no separate reports on the intracranial repair of nerves eight, nine, 10, 11, or 12. Only Sekhar, et al.,[79] mention in their paper on temporal bone tumors repair of the glossopharyngeal, vagal, and accessory nerve in four cases using cable grafts. However, the clinical course and recovery of these repairs were not described. Matthies, et al.,[51] report on accessory nerve repair with nerve grafting after meningioma removal in the cerebellopontine angle. Nine months after surgery motor recovery had proceeded up to Grade M3 (muscle contraction against gravity).

\section{DISCUSSION}

Aggressive surgical strategies for skull base lesions will increase cranial nerve lesions. Compared to peripheral nerve surgery, intracranial nerve surgery is still an unexplored area. Although interest in cranial nerve regeneration emerged as early as $1938,[5,6]$ the first clinical report on intracranial nerve repair (except the facial nerve) was not published until 1982.[38] Although most of the clinical literature consists of case reports, some conclusions and recommendations can be postulated. Moreover, some basic neuropathological considerations and controversies will be outlined that should raise further points for future discussion and research.

\section{Coaptation Technique}

Because of the anatomical and histological considerations outlined earlier, operative reconstruction of cranial nerves is only practical as a loose coaptation of the cut ends by meticulous microsurgical techniques. The use of interfascicular suture, which is recommended to avoid misdirection in peripheral nerves,[56,57] is absolutely unfeasible and impossible in this setting. Of all factors influencing nerve recovery, the timing and technique of nerve repair are the only two factors over which the surgeon has direct influence. The slight, if any, advantage of an optimal metabolic state of the nerve cell for regeneration when a secondary repair is performed (that is, usually 3 weeks after transection) does not justify a second intracranial operation. The studies described above show that even repair of the smallest cranial nerve (trochlear nerve) is feasible; however, technical problems may arise in accomplishing accurate coaptation of the small and fragile structure. The most established surgical method for nerve 
repair, one involving suture repair with fine surgical thread (8-0 to 11-0 nylon), poses several disadvantages. The sutures may be difficult to place and are easily torn from the tissue. Moreover, they may cause mechanical damage during insertion, result in a foreign body reaction, or scar and neuroma formation: all of which have negative effects on the functional outcome. Finally, a high level of surgical skill is required to perform suture repair. As regenerating axons advance by a push-pull mechanism, it is obvious that productive and blocking changes in the tissue around and between the ends of nerve sutures cause impaired regeneration. In addition, from studies on spinal nerves (which are histologically similar to cranial nerves) it appears that histiocytic cells are present in the tissue during wound healing and contribute to the thickening of the nerve sheaths after microsurgical suture repair.[54] This may impair the nutritional conditions of axons and supportive cells, because t he normally thin perineurial layers of the nerves, which lack a continuous basal lamina, suggest a metabolic interrelationship between CSF and the endoneurial compartment of the nerves. Consequently, repeated attempts have been made to find a "suture-free" repair technique. Currently, different methods of coaptation have been described for cranial nerve repair such as the use of fenestrated collagen splints,[29] microfibrillar collagen tubes,[3] fibrin glues,[40] and lasers.[45]

The use of fibrin glue for nerve repair is based on the bonding properties of two substances, thrombin and fibrinogen, when they are mixed.[60,85] The results of the use of fibrin glue in experimental studies in peripheral and cranial nerves are very contrasting.[12,53,85,89] In cranial nerve repair, Sandvoss, et al.,[71,72] claim superior results with fibrin glue, whereas Seifert and Stolke[75,76] found a high dehiscence percentage and only partial recovery of the nerves coapted with fibrin glue. No specific explanation is given for these failures, but it seems to be related to the low bonding strength of fibrin glue. On the other hand, the use of a plasma clot, which is considered an inferior alternative to the commercially available fibrin glue (Tissucol), gave excellent results in rats, showing no dehiscence and good regeneration. As can be concluded from the histological figures in the paper of Fernandez, et al.,[26] the plasma clot produced a very accurate coaptation without scarring, neuroma, or inflammation. In conclusion, supported also by the clinical reports (Tables 1 and 3), there are few reasons why fibrin glue should not be used in an absolutely tension free repair of cranial nerves.

Laser welding is another alternative method for sutureless nerve repair.[55] It is a photothermal process using laser energy to join tissues, resulting in alteration of the molecular structure of the tissue being joined. The altered tissue molecules form bonds with their neighbors. The $\mathrm{CO} 2$ milliwatt laser attached to the surgical microscope with a micromanipulator offers advantages such as precise spatial and temporal confinement of the applied energy that enables very localized microsurgery, which could be important, especially in areas of limited surgical access and areas involving delicate structures such as the brainstem. This was clearly demonstrated by Seifert and Stolke[75,76] who repaired the oculomotor nerve in cats and found that suture repair was not feasible because of the limited operating field. Moreover, laser repair offers the advantages that it is nontactile, induces no foreign body reaction, and the bond is definite.[55] Animal studies showed that laser-assisted nerve repair is superior to sutures in peripheral nerve repair[4,11,30] and superior to fibrin glue in cat cranial nerve repair.[75,76] Clinically, laser-assisted cranial nerve repair has been performed in a few cases by Powers using Gelfoam as a supporting membrane.[45]

\section{End-to-End Versus Graft Repair}

End-to-end repair at the time of initial surgery is now considered to be the management of choice. However, when a gap exists between the nerve ends, direct approximation carries the risk of creating 
tension at the repair site (causing connective tissue proliferation and thus being detrimental to nerve regeneration), dehiscence in the postoperative period, or unnecessary stretching of the nerve (with concomitant damage to the nerve and transition zone). For the cranial nerves three and six an end-to-end repair is not possible if the gap exceeds $3 \mathrm{~mm}$.[77] In these cases nerve grafting should be performed. In peripheral nerve surgery it has been proven that grafting with an autologous nerve gives the best results for histological and functional recovery.

Theoretically, it seems to us that the use of a peripheral nerve graft may be beneficial, not simply from a mechanical point of view. First, the peripheral nerve graft with its firm epineurium and perineurium can be attached to the cranial nerve stump, providing support for the sutures. Second, the connective tissue in the peripheral nerve serves as anatomical structure and guidance for growing axons, full of local factors promoting nerve regeneration. [50] In this aspect it is noteworthy that the perineurial cells in the peripheral nerve graft are the first to be involved in the cellular connection between the nerve stumps.[74] In addition, the basal lamina in the peripheral nerve is an excellent substrate for the growth of nerve fibers. $[10,14,35]$ It provides the tracks guiding the growing axon sprouts to the target tissue. Nevertheless, these advantages must outweigh the disadvantages of grafting. In addition to harvesting the nerve graft, two graft repair sites have to be crossed by the regenerating axons. Axonal loss at each repair site may be considerable, especially in poorly performed repairs; some axons may be blocked by developing scar tissue, others may be misdirected as they advance and ultimately fail to reach and establish appropriate connections with functionally related end organs. Only Jääskeläinen, et al.,[39] question the suitability of a peripheral nerve graft. In their report, the best result was achieved in a patient in whom the statoacoustic nerve was used as a graft. Future experiments are necessary to clarify this issue.

For the reasons above described, when grafting is necessary, autologous nerve tissue should be taken. The posterior auricular nerve is recommended because of its anatomical proximity and its similar diameter. Alternatives include cervical, sural, supraorbital, or branches of the radial nerve. Nevertheless, Glasby, et al.,[32] successfully used freeze-thawed muscle autograft for cranial nerve grafting in a sheep model and in two clinical cases of facial nerve repair in the cerebellopontine angle. This muscle autograft is an oriented basement membrane matrix that does not contain Schwann cells. Therefore, it performs only over a short distance, most likely because it lacks Schwann cells. Its clinical use must be proven in the near future.

\section{Recovery of Function}

Functional recovery after nerve suturing depends primarily on reestablishment of appropriate sensory and motor connections and the preexistent function of the muscle-nerve unit. Although only a limited number of cranial nerve repairs have been performed, some considerations in the expected recovery can be postulated. Pure motor nerves are likely to regenerate better than mixed nerves where the possibility of fibers regenerating down inappropriate sheaths exists, whereas nerves innervating only one muscle have a better prognosis, eliminating functional compromise due to aberrant regeneration. Good prognosis can be expected in the fourth and sixth nerve because they are purely motor nerves, having only one muscle to innervate (Table 1). In these nerve repairs, binocular function was improved. Concerning the oculomotor nerve, only partial return of function can be expected because it is a complex nerve supplying six different muscles with specific function. The difficulty does not lie in the inadequate regenerative response, but in the apparent randomness with which regenerating axons form connections with their target organs. The axons terminate in ocular muscles other than those they originally 
innervated. A classic sign of aberrant innervation consists of the mass movement of all the muscles supplied by the nerve. The reason for the failure of central reorganization of oculomotor function after regeneration remains unclear. Nevertheless, repairing the oculomotor nerve is beneficial from a cosmetic point of view. Almost all patients with oculomotor nerve repair showed useful recovery of nerve function, which prevented diplopia on horizontal gaze position (Table 1).

After facial nerve repair, patients often exhibit the phenomenon of synkinesis in the form of associated movements, mass action, or blinking tic occurring during voluntary or reflex activity. Excellent recovery cannot be achieved; once the nerve is divided, subtle facial movements are permanently lost. Nevertheless after facial nerve repair a high percentage of patients $(50 \%)$ have good or fair results, regardless of the type of repair (Table 3). The major advantage of appropriate direct facial nerve repair is the restoration of facial tone at rest, degree of voluntary motion and possibility of facial motion with emotional expression. $[9,39]$ Only in $25 \%$ of patients does poor or no recovery occur. The cause may be dehiscence of the repair site $[8,52]$ in the postoperative period or severe preexistent facial nerve deficit.[86] Jääskeläinen, et al.,[39] found that the type of repair and the number of sutures were not associated with poor outcome. The mean time between surgery and start of the recovery is usually 6 months, [40,42] with a range of $4[3,42]$ to several years.[66] Although some authors state that after 2 years, further recovery of the facial nerve function cannot be expected,[3,42] it is generally accepted that maximum recovery after facial nerve repair can proceed for up to 10 years after surgery.

In cases of failure after primary facial repair, secondary reanimation techniques such as hypoglossal-facial nerve coaptation will still produce a reasonable degree of recovery.[42,52,70] In general, patients with a hypoglossal-facial nerve coaptation can achieve a House and Brackmann Grade IV or in some instances even a Grade III. $[42,70]$ This technique gives good voluntary and occasionally some emotional movement after a long duration of practice and training. Other substitution techniques such as cross-nerve-facial nerve coaptation also achieve acceptable results, that is, a House and Brackmann Grade III in $50 \%$ of the cases.[52,70]

Limited information has been published on the recovery of other cranial nerves after repair. It seems reasonable to conclude that at least some functional recovery can occur after repair, especially in those cases with normal preoperative function. Consequently, every cranial nerve transection should be considered for repair, with the exception of the vestibulocochlear nerve. This nerve has a very long central portion[66] and must be considered as being a part of the central nervous system and thus to have poor regenerative potential.

The difference between the duration of anatomical recovery in clinical models and functional recovery in humans cannot be explained solely by the difference in the speed of regenerative response. After anatomical restoration of the nerve, peripheral deletion of maladaptive terminations and central remodeling of reflex arcs continue, which offers additional possibilities for functional recovery. Incorrect peripheral reinnervation leads to a new pattern of sensory impulses in afferent fibers and to a new cortical projection of peripheral cutaneous areas and motor representation. Thus, although the complexity of peripheral factors influencing axonal regeneration is striking, the central nervous system component of the problem is equally important. Sensory reeducation, implying a detailed program for cerebral adaptation to the new situation, represents an important component of rehabilitation following nerve injuries.

Finally, difficulties arise as to how to evaluate the recovery of the cranial nerves objectively, especially 
those with complex function such as the oculomotor nerve. For the facial nerve, a uniform test has been established by the House and Brackmann grading system.[36] For other nerves, several tests have been proposed but none of them is widely accepted.[7,79] Future studies will be necessary to address this complex issue.

\section{CONCLUSIONS}

Cranial nerve injury ranks high in terms of morbidity and disability after skull base surgery. Since the first clinical report by Dott,[16] intracranial facial nerve repair is currently used by many surgeons. Subsequently, other cranial nerves have been repaired with a satisfactory degree of functional recovery. The results of these studies should encourage attempts to surgically repair cranial nerve injuries and to elicit further interest in this exciting research area.

\section{References}

1. Arriaga MA, Brackmann DE: Facial nerve repair techniques in cerebellopontine angle tumor surgery. Am J Otol 13:356-359, 1992

2. Baldwin HZ, Miller CG, van LH, et al: The far lateral/combined supra- and infratentorial approach. A human cadaveric prosection model for routes of access to the petroclival region and ventral brain stem. $\mathbf{J}$ Neurosurg 81:60-68, 1994

3. Barrs DM, Brackmann DE, Hitselberger WE: Facial nerve anastomosis in the cerebellopontine angle: a review of 24 cases. Am J Otol 5:269-272, 1984

4. Beggs JL, Fischer DW, Shetter AG: Comparative study of rat sciatic nerve microepineurial anastomoses made with carbon dioxide laser and suture techniques: Part 2. A morphometric analysis of myelinated nerve fibers. Neurosurgery 18:266-269, 1986

5. Bender MB, Fulton JF: Functional recovery in ocular muscles of chimpanzee after section of oculomotor nerve. J Neurophysiol 1:144-151, 1938

6. Bender MB, Fulton JF: Factors in functional recovery following section of the oculomotor nerve in monkeys. J Neurol Psychiatry 2:285-292, 1939

7. Biglan AW, Sekhar LN, Cheng KP, et al: A protocol for measuring ophthalmologic morbidity and recovery after cranial base surgery. Skull Base Surg 4:26-31, 1994

8. Blomstedt GC, Jaaskelainen JE, Pyykko I, et al: Recovery of the sutured facial nerve after removal of acoustic neuroma in patients with neurofibromatosis-2. Neurosurgery 35:364-369, 1994

9. Brackmann DE, Hitselberger WE, Robinson JV: Facial nerve repair in cerebellopontine angle surgery. Ann Otol Rhinol Laryngol 87:772-777, 1978

10. Bunge RP: Tissue culture observations relevant to the study of axon-Schwann cell interactions during peripheral nerve development and repair. J Exp Biol 132:21-34, 1987

11. Campion ER, Bynum DK, Powers SK: Repair of peripheral nerves with the argon laser. A functional and histological evaluation. J Bone Joint Surg (Am) 72:715-723, 1990

12. Cruz NI, Debs N, Fiol RE: Evaluation of fibrin glue in rat sciatic nerve repairs. Plast Reconstr Surg 
13. Daspit CP, Spetzler RF, Pappas CT: Combined approach for lesions involving the cerebellopontine angle and skull base: experience with 20 cases--preliminary report. Otolaryngol Head Neck Surg 105:788-796, 1991

14. de Medinaceli L: Functional consequences of experimental nerve lesions: effects of reinnervation blend. Exp Neurol 100:166-178, 1988

15. Deruty R, Guyotat J, Mottolese C, et al: [Partial recovery of the oculomotor nerve after section and repair during the excision of a tumor.] Neurochirurgie 34:287-292, 1988 (Fr)

16. Dott NM: Facial paralysis; restitution by extrapetrous nerve graft. Proc R Soc Med 51:900-902, 1958

17. Dott NM: Facial nerve reconstruction by graft bypassing the petrous bone. Arch Otolaryngol 78:426-428, 1963

18. Draf W: Surgical rehabilitation of facial nerve. Acta Neurochir 92:67-75, 1988

19. Drake CG: Acoustic neuroma. Repair of facial nerve with autogenous graft. J Neurosurg 17:836-842, 1960

20. Drake CG: Intracranial facial nerve reconstruction. Arch Otolaryngol 78:456-460, 1963

21. Drake CG: Surgical treatment of acoustic neuroma with preservation or reconstitution of the facial nerve. J Neurosurg 26:459-464, 1967

22. Drake CG: Facial function after intracranial repair of facial nerve. Arch Otolaryngol 95:420-425, 1972

23. Dubuisson A, Kline DG: Indications for peripheral nerve and brachial plexus surgery. Neurol Clin 10:935-951, 1992

24. Ebersold MJ, Harner SG, Beatty CW, et al: Current results of the retrosigmoid approach to acoustic neurinoma. J Neurosurg 76:901-909, 1992

25. Fernandez E, Pallini R, Gangitano C, et al: The third nerve transection and regeneration in rats with preliminary results on the sixth nerve transection and regeneration in guinea pigs. Neurol Res 10:221-224, 1988

26. Fernandez E, Pallini R, Gangitano C, et al: Oculomotor nerve regeneration in rats. Functional, histological, and neuroanatomical studies. J Neurosurg 67:428-437, 1987

27. Fernandez E, Pallini R, Sbriccoli A: Changes in the central representation of the extraocular muscles in the rat oculomotor nucleus after section and repair of the third cranial nerve. Neurol Res 7:199-201, 1985

28. Ferrier R, Padmanabhan V, Hunn A, et al: Successful outcome following anastomosis of a severed trochlear nerve in the middle fossa. Aust N Z J Ophthalmol 20:133-136, 1992

29. Fisch U, Dobie RA, Gmur A, et al: Intracranial facial nerve anastomosis. Am J Otol 8:23-29, 1987 
30. Fischer DW, Beggs JL, Kenshalo DL Jr, et al: Comparative study of microepineurial anastomoses with the use of $\mathrm{CO}_{2}$ laser and suture techniques in rat sciatic nerves: Part 1. Surgical technique, nerve action potentials, and morphological studies. Neurosurgery 17:300-308, 1985

31. Fritschi JA, Reulen HJ, Spetzler RF, et al: Cavernous malformations of the brain stem. A review of 139 cases. Acta Neurochir 130:35-46, 1994

32. Glasby MA, Clutton RE, Drew SJ: Repair of the facial nerve in the cerebellopontine angle using freeze-thawed skeletal muscle autografts. An experimental surgical study in the sheep. Acta Neurochir 136:151-159, 1995

33. Graeber MB, Tetzlaff W, Streit WJ, et al: Microglial cells but not astrocytes undergo mitosis following rat facial nerve axotomy. Neurosci Lett 85:317-321, 1988

34. Grimson BS, Ross MJ, Tyson G: Return of function after intracranial suture of the trochlear nerve. Case report. J Neurosurg 61:191-192, 1984

35. Hall SM: The effect of inhibiting Schwann cell mitosis on the re-innervation of acellular autografts in the peripheral nervous system of the mouse. Neuropathol Appl Neurobiol 12:401-414, 1986

36. House JW, Brackmann DE: Facial nerve grading system. Otolaryngol Head Neck Surg 93:146-147, 1985

37. Hudson AR, Dommisse I: Brachial plexus injury. Can Med Assoc J 117:1162-1164, 1977

38. Iwabuchi T, Suzuki M, Nakaoka T, et al: Oculomotor nerve anastomosis. Neurosurgery 10:490-491, 1982

39. Jääskeläinen J, Pyykkö I, Blomstedt G, et al: Functional results of facial nerve suture after removal of acoustic neurinoma: analysis of 25 cases. Neurosurgery 27:408-411, 1990

40. Kanzaki J, Kunihiro T, O-Uchi T, et al: Intracranial reconstruction of the facial nerve. Clinical observation. Acta Otolaryngol Suppl 487:85-90, 1991

41. King TT, Morrison AW: Primary facial nerve tumors within the skull. J Neurosurg 72:1-8, 1990

42. King TT, Sparrow OC, Arias JM, et al: Repair of facial nerve after removal of cerebellopontine angle tumors: a comparative study. J Neurosurg 78:720-725, 1993

43. Kline DG: Perspectives concerning brachial plexus injury and repair. Neurosurg Clin North Am 2:151-164, 1991

44. Krajewski R: Oculomotor nerve repair using interposed nerve graft. Neurosurgery 30:591-594, 1992

45. Krishnamurthy S, Powers SK: Lasers in neurosurgery. Lasers Surg Med 15:126-167, 1994

46. Krisht A, Barnett DW, Barrow DL, et al: The blood supply of the intracavernous cranial nerves: an anatomic study. Neurosurgery 34:275-279, 1994

47. Lang J: [Neuroanatomy of the optic, trigeminal, facial, glossopharyngeal, vagus, accessory and hypoglossal nerves.] Arch Otorhinolaryngol 231:1-69, 1981 (Ger) 
48. Lang J: [Anatomy, length and blood vessel relations of "central" and "peripheral" paths of intracisternal cranial nerves.] Zentralbl Neurochir 43:217-258, 1982 (Ger)

49. Luetje CM, Whittaker CK: The benefits of VII-VII neuroanastomosis in acoustic tumor surgery. Laryngoscope 101:1273-1275, 1991

50. Madison RD, Archibald SJ: Point sources of Schwann cells result in growth into a nerve entubulation repair site in the absence of axons: effects of freeze-thawing. Exp Neurol 128:266-275, 1994

51. Matthies C, Carvalho G, Tatagiba M, et al: Meningiomas of the cerebellopontine angle. Acta Neurochir 65:86-91, 1996

52. May M: The Facial Nerve. New York: Thieme, 1986

53. Medders G, Mattox DE, Lyles A: Effects of fibrin glue on rat facial nerve regeneration. Otolaryngol Head Neck Surg 100:106-109, 1989

54. Meier C, Sollmann H: Regeneration of cauda equina fibres after transsection and end-to-end suture. Light and electron microscopic study in the pig. J Neurol 215:81-90, 1977

55. Menovsky T, Beek JF, Thomsen SL: Laser(-assisted) nerve repair: a review. Neurosurg Rev 18:225-235, 1995

56. Millesi H: Interfascicular grafts for repair of peripheral nerves of the upper extremity. Orthop Clin North Am 8:387-404, 1977

57. Millesi H, Meissl G, Berger A: Further experience with interfascicular grafting of the median, ulnar, and radial nerves. J Bone Joint Surg (Am) 58:209-218, 1976

58. Minami M, Ishii S: Satisfactory elbow flexion in complete (preganglionic) brachial plexus injuries: produced by suture of third and fourth intercostal nerves to musculocutaneous nerve. J Hand Surg (Am) 12:1114-1118, 1987

59. Moffat DA, Croxson GR, Baguley DM, et al: Facial nerve recovery after acoustic neuroma removal. J Laryngol Otol 103:169-172, 1989

60. Narakas A: The use of fibrin glue in repair of peripheral nerves. Orthop Clin North Am 19:187-199, 1988

61. Nathan H, Goldhammer Y: The rootlets of the trochlear nerve. Anatomical observations in human brains. Acta Anat 84:590-596, 1973

62. Nathan H, Ouaknine G, Kosary IZ: The abducens nerve. Anatomical variations in its course. J Neurosurg 41:561-566, 1974

63. Nemecek S, Parizek J, Spacek J, et al: Histological, histochemical and ultrastructural appearence of the transitional zone of the cranial and spinal nerve roots. Folia Morphologica 27:171-181, 1969

64. Pallini R, Fernandez E, Lauretti L, et al: Experimental repair of the oculomotor nerve: the anatomical paradigms of functional regeneration. J Neurosurg 77:768-777, 1992

65. Pisaneschi MJ, Mafee MF, Samii M: Applications of MR angiography in head and neck pathology. 
Otolaryngol Clin North Am 28:543-561, 1995

66. Pluchino F, Fornari M, Luccarelli G: Intracranial repair of interrupted facial nerve in course of operation for acoustic neurinoma by microsurgical technique. Acta Neurochir 79:87-93, 1986

67. Roland JT Jr, Hammerschlag PE, Lewis WS, et al: Management of traumatic facial nerve paralysis with carotid artery cavernous sinus fistula. Eur Arch Otorhinolaryngol 251:57-60, 1994

68. Saitoh K: [Oculomotor nerve anastomosis: an experimental study in the dog.] No Shinkei Geka 12:1359-1366, 1984 (Jpn)

69. Samii M: Facial nerve grafting in acoustic neurinoma. Clin Plast Surg 11:221-225, 1984

70. Samii M, Matthies C: Indication, technique and results of facial nerve reconstruction. Acta Neurochir 130:125-139, 1994

71. Sandvoss G, Cervos-Navarro J, Yasargil MG: Intracranial repair of the oculomotor nerve in cats. Neurochirurgia 29:1-8, 1986

72. Sandvoss G, Stoltenburg-Didinger G, Yasargil MG: Experimental transclival exposure and repair of the abducens nerve in cats. Neurochirurgia 30:65-68, 1987

73. Schoen SW, Kreutzberg GW: Synaptic 5'-nucleotidase activity reflects lesion-induced sprouting within the adult rat dentate gyrus. Exp Neurol 127:106-118, 1994

74. Schroder JM, May R, Weis J: Perineurial cells are the first to traverse gaps of peripheral nerves in silicone tubes. Clin Neurol Neurosurg Suppl 95:578-583, 1993

75. Seifert V, Stolke D: Laser-assisted reconstruction of the oculomotor nerve: experimental study on the feasibility of cranial nerve repair. Neurosurgery 25:579-582, 1989

76. Seifert V, Stolke D, Goetz C: [Microsurgery, laser-assisted cranial nerve anastomosis. An experimental study.] Handchir Mikrochir Plast Chir 22:82-87, 1990 (Ger)

77. Sekhar LN, Burgess J, Akin O: Anatomical study of the cavernous sinus emphasizing operative approaches and related vascular and neural reconstruction. Neurosurgery 21:806-816, 1987

78. Sekhar LN, Kalia KK, Yonas H, et al: Cranial base approaches to intracranial aneurysms in the subarachnoid space. Neurosurgery 35:472-481, 1994

79. Sekhar LN, Lanzino G, Sen CN, et al: Reconstruction of the third through sixth cranial nerves during cavernous sinus surgery. J Neurosurg 76:935-943, 1992

80. Sekhar LN, Pomeranz S, Janecka IP, et al: Temporal bone neoplasms: a report on 20 surgically treated cases. J Neurosurg 76:578-587, 1992

81. Sekhar LN, Pomeranz S, Sen CN: Management of tumours involving the cavernous sinus. Acta Neurochir Suppl 53:101-112, 1991

82. Sepehrnia A, Samii M, Tatagiba M: Management of intracavernous tumours: an 11-year experience. Acta Neurochir Suppl 53:122-126, 1991 
83. Sindou M, Gilg A, Vighetto A, et al: Cryptic angioma in the trochlear nerve. Excision of the invaded portion and successful repair with an autologous graft: case report. Neurosurgery 30:255-258, 1992 84. Skinner HA: Some histologic features of the cranial nerves. Arch Neurol Psychiatry 25:356-372, 1931

85. Smahel J, Meyer VE, Bachem U: Glueing of peripheral nerves with fibrin: experimental studies. J Reconstr Microsurg 3:211-220, 1987

86. Stephanian E, Sekhar LN, Janecka IP, et al: Facial nerve repair by interposition nerve graft: results in 22 patients. Neurosurgery 31:73-76, 1992

87. Tarlov IM: Structure of nerve root: nature of junction between central and peripheral nervous system. Arch Neurol 37:555-583, 1937

88. Tetzlaff W, Bisby MA, Kreutzberg GW: Changes in cytoskeletal proteins in the rat facial nucleus following axotomy. J Neurosci 8:3181-3189, 1988

89. Ventura R, Torri G, Campari A, et al: Experimental suture of the peripheral nerves with "fibrin glue". Ital J Orthop Traumatol 6:407-414, 1980

90. Yasargil MG, Smidh RD, Yasser JC: Microsurgical approach to acoustic neurinoma., in Krayenbuhl H, Brihaye J, Loew F, et al. (eds): Advances and Technical Standards in Neurosurgery. Wien: Springer -Verlag, 1977

Manuscript received June 14, 1996.

Accepted in final form July 18, 1996.

Address reprint requests to: Tomas Menovsky, M.D., Department of Neurosurgery, Academic Hospital Nijmegen St. Radboud, P.O. Box 9101, 6500 HB Nijmegen, The Netherlands. 